\title{
Acute Inflammatory Myalgia: Think of Myositis Ossificans Circumscripta
}

ABEL GALEANO, MD; JEAN-BAPTISTE FRAISON, MD, Clinical Immunology and Osteoarticular Diseases Therapeutic Unit, Lapeyronie University Hospital, Montpellier; PIERRE VIALA, MD, Department of Radiology, Lapeyronie Hospital, Montpellier; PIERRE LE BLAY, MD, CHRISTIAN JORGENSEN, MD, $\mathrm{PhD}$; YVES-MARIE PERS, MD, Clinical Immunology and Osteoarticular Diseases Therapeutic Unit, Lapeyronie University Hospital, Montpellier, France. Address correspondence to Dr. Y-M. Pers, Clinical Immunology and Osteoarticular Diseases Therapeutic Unit, CHRU Lapeyronie, 371 avenue du doyen Gaston Giraud, 34295 Montpellier, France. E-mail: ym-pers@chu-montpellier.fr. J Rheumatol 2013;40:1614-15; doi:10.3899/jrheum.130040

Myositis ossificans circumscripta (MOC) is a form of heterotopic ossification in extraskeletal soft tissues that is benign, but may appear clinically and radiologically as a malignant neoplasm ${ }^{1}$.

An 18-year-old woman had sudden pain in her left thigh with functional impairment, without trauma. Examination revealed an indurated mass on the upper third of the thigh. Laboratory analyses were normal except for a C-reactive protein level at $35 \mathrm{mg} / \mathrm{l}$ (normal $<3 \mathrm{mg} / \mathrm{l}$ ). Magnetic resonance imaging (MRI), computed tomography (CT), and radiographs of the left thigh (Figure 1) were typical of
MOC. Treatment with steroids and bisphosphonate infusion was effective for pain.

MOC is a rare benign disorder and imaging is characteristic $^{2}$. It can be observed at any age, but especially in adolescents and young adults. MOC affects mainly extremities ${ }^{2}$ and trauma is often implicated $(70 \%)^{2}$. Bone scintigraphy seems very sensitive, showing increased uptake over the lesion $^{3}$. CT scanning illustrates the typical imaging features of MOC with a rim of calcification around the lesion, a perilesional edema without bone marrow or cortical abnormalities $^{4}$. MRI findings depend on the stage of maturation

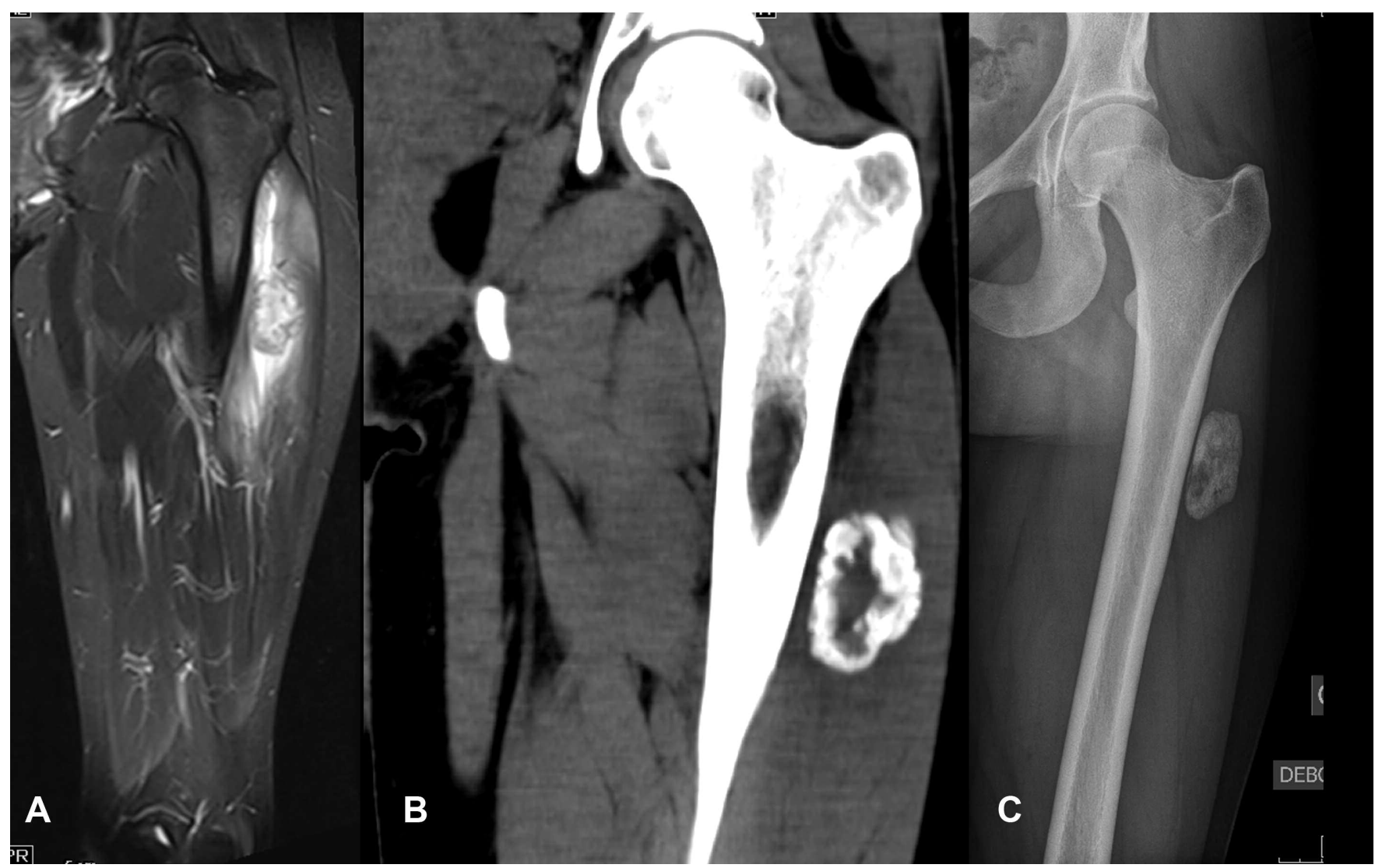

Figure 1. A. Coronal fat-suppressed T2-weighted MRI image at early stage shows an ovoid mass of diameter 4 mm within the vastus lateralis muscle associated with extensive peripheral edema-like signal in adjacent muscle. B. Coronal CT reconstruction image 2 weeks later: calcifications surrounding a hypodense area in the left vastus lateralis muscle, without infiltration of the femoral bone or periosteal reaction. C. Anteroposterior radiograph of the left proximal femur 6 months later: sharply circumscribed osseous mass in projection of the vastus lateralis muscle demonstrating typical zoning pattern of mineralization (rim of mature bone peripherally). MRI: magnetic resonance imaging; CT: computed tomography.

Personal non-commercial use only. The Journal of Rheumatology Copyright @ 2013 . All rights reserved. 
and histological pattern of the lesion ${ }^{3}$. T2-weighted images show a heterogeneous localized mass with high signal intensity in the central area $^{3}$. Without the characteristic imaging signs, biopsy is necessary to determine the difference between bone and soft-tissue malignancy ${ }^{1,5}$ such as paraosteal sarcoma, rhabdomyosarcoma, malignant fibrous histiocytoma, or osteoblastic metastasis.

\section{REFERENCES}

1. Gould CF, Ly JQ, Lattin GE Jr, Beall DP, Sutcliffe JB 3rd. Bone tumor mimics: avoiding misdiagnosis. Curr Probl Diagn Radiol 2007;36:124-41.
2. Micheli A, Trapani S, Brizzi I, Campanacci D, Resti M, de Martino M. Myositis ossificans circumscripta: a paediatric case and review of the literature. Eur J Pediatrics 2009;168:523-9.

3. Parikh J, Hyare H, Saifuddin A. The imaging features of posttraumatic myositis ossificans, with emphasis on MRI. Clin Radiol 2002;57:1058-66.

4. Wang XL, Malghem J, Parizel PM, Gielen JL, Vanhoenacker F, De Schepper AM. Pictorial essay. Myositis ossificans circumscripta. JBR-BTR 2003;86:278-85.

5. Aneiros-Fernandez J, Caba-Molina M, Arias-Santiago S, Ovalle F, Hernandez-Cortes P, Aneiros-Cachaza J. Myositis ossificans circumscripta without history of trauma. J Clin Med Res 2010;2:142-4 